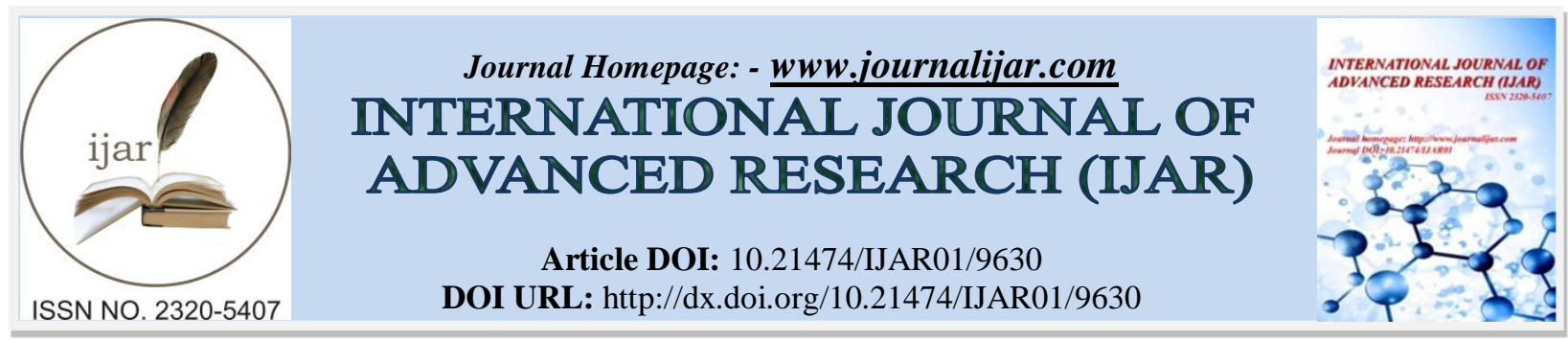

RESEARCH ARTICLE

\title{
THE VULNERABILITY OF MAIZE PRODUCTIVITY BASED ON WATER BALANCE AND CLIMATE DYNAMICS FLUCTUATIONS IN GORONTALO PROVINCE.
}

Wawan Pembengo, Yunita Rahim and Suyono Dude.

Department of Agrotechnology, Faculty of Agriculture Universitas Negeri Gorontalo.

\section{Manuscript Info}

Manuscript History

Received: 02 July 2019

Final Accepted: 04 August 2019

Published: September 2019

Key words:-

Vulnerability productivity, water balance, climate dynamics.

\section{Abstract}

There is a vulnerability with correction in maize production if happened water stress due to fluctuations in water balance and climate dynamics in Gorontalo Province. This study aims to determine the vulnerability of maize productivity based on fluctuations in water balance and climate dynamics in Gorontalo Province. The study was conducted from May to October 2017. The study sites are located between $0^{0} 19^{\prime}-1^{0} 15^{\prime}$ North Latitude and $121^{0} 23$ '- $123^{0} 43^{\prime}$ East Longitude. 4 locations that represent the regency of Gorontalo (Bumela), Kab Boalemo (Dulupi), Bone Bolango (Suwawa) and Kab Pohuwato (Marisa). The data used in this study is daily climate data for 20 years (1997 to 2016) involved rainfall, solar radiation, maximum and minimum air temperature, duration of transmission, humidity and wind speed. Data on planting area, harvested area (production) and corn harvest failure in Gorontalo Province in the last 20 years. Supporting data is the administrative map of Gorontalo Province, map of agro climate zone. This research uses the method of analysis of land water balance model where evapotranspiration method analysis using the FAO Penman-Monteith method. Generally, Gorontalo Province has the first deficit month period in July, August, September, October where during this period there is a potential vulnerability of maize production due to water shortage. The period of the first month of the surplus in November, December, January where during this period there is potential for corn production resistance due to water availability. The second deficit period is February, March was during this period potentially less vulnerable due to short deficit period compared to the period of the first deficit month. The second surplus period is April, May, June where this period is potentially less resistant because the number and duration of rainfall are relatively less than the first surplus period. The susceptibility and resistance of maize production are influenced by the amount of supply and duration (duration of the period) of regional rainfall and the application of adaptation technology to drought and flood disasters.

Copy Right, IJAR, 2019,. All rights reserved.

Corresponding Author:-Wawan Pembengo.

Address:-Department of Agrotechnology, Faculty of Agriculture Universitas Negeri Gorontalo. 


\section{Introduction:-}

The droughts and floods disaster are the dominant and decisive factor in the increase of maize production. Hakim (2008) states that drought is the event when the amount of rainfall under normal conditions resulting in a decrease in water production for agricultural purposes while flooding is an event when the river flow exceeds the capacity of the river catchment. In Gorontalo, technical irrigation lands are still lower than rain-fed areas, dependence on rainfall is especially accurate information when the right time get into the rainy and dry seasons. The most common problem is the high level of vulnerability (easily corrected) of maize productivity based on water balance and fluctuation of climate dynamics in Gorontalo Province. Hassanli et al. (2009) suggested that there is a big challenge for the agricultural sector in the form of how to increase agricultural productivity, especially corn when water resources are limited and the uncertainty of the growing season due to climate change.

Deficiency of water resources has been a major concern of sustainable crop production. In the last few decades, there has been a tendency to increase demand for agricultural water, the variability of soil moisture (Tao and Zhang, 2010). The high sensitivity of maize to water stress means that under conditions of limited water it is difficult to implement irrigation management strategies without causing significant yield losses (Farre and Faci, 2009). Payero et al. (2009) state that if the water is limited, it is important how to know predicted the right irrigation to optimize crop yield and water use efficiency. Ko and Piccinni (2009) argue that the application of irrigation in the muchneeded phase of corn is important because it saves water and sustains crop yields. The yield of corn kernels is influenced by many environmental factors such as water availability, weather conditions of the growing season and soil conditions. Farmers with limited water often have to choose between options such as partially irrigating a field, irrigating larger plant areas, changing crops that require less water, or investing in more efficient irrigation systems.

Evapotranspiration is one of the important steps in planning, designing and implementing irrigation management system and water resources management. Suyker and Verma (2009) suggest that large rates of evapotranspiration affect water content, improve water use efficiency and reduce water sources in agricultural areas. Katerji and Rana (2006) state that the value of the crop evapotranspiration irrigated can be calculated directly using the FAO PenmanMonteith method by using specific plant parameters and meteorological parameters (weather). Cai et al. (2007) suggest that the daily reference evapotranspiration prediction which to base estimates of crop evapotranspiration (ETC) Penman-Monteith method is recommended for prediction of environmental parameters and the reference plants in the field is relatively accurate. Thus there is a need for depth research on the vulnerability of maize production to drought and flood-related to extreme climate which has the potential to cause a decrease in the planting area, harvested area and productivity of local and national maize which will eventually lead to national food security.

\section{Materials And Methods:-}

The study was conducted from May to October 2017. The study sites are located between $0^{0} 19^{\prime}-1^{0} 15^{\prime}$ North Latitude and $121^{\circ} 23$ '- $123^{\circ} 43^{\prime}$ East Longitude. 4 locations represent the regency of Gorontalo (Bumela), Kab Boalemo (Dulupi), Bone Bolango (Suwawa) and Kab Pohuwato (Marisa). The data used in this study is daily climate data for 20 years (1997 to 2016) involved rainfall, solar radiation, maximum and minimum air temperature, duration of transmission, humidity and wind speed. Data on planting area, harvested area (production) and corn harvest failure in Gorontalo Province in the last 20 years. Supporting data is the administrative map of Gorontalo Province, map of agro climate zone. This research uses the method of analysis of land water balance model where evapotranspiration method analysis using the FAO Penman-Monteith method.

Stages of land water balance calculations

\section{Calculate monthly rainfall}

Calculate potential evapotranspiration (ETp) using the FAO Penman-Monteith method. The FAO-Penman Monteith equation recommended for daily ETo $\left(\mathrm{mm} \mathrm{day}^{-1}\right)$ estimation (Allen et al., 1998) may be written as :

$$
\text { (1)..................................... } \mathrm{ET}_{0}=\frac{0,408 \Delta\left(\mathrm{R}_{\mathrm{n}}-\mathrm{G}\right)+\gamma\left(900 /(\mathrm{T}+273) \mathrm{U}_{2}(\mathrm{es}-\mathrm{ea})\right.}{\Delta+\gamma\left(1+0,34 \mathrm{u}_{2}\right)}
$$

where $\mathrm{ET}_{0}$ is standard evapotranspiration, $\mathrm{R}_{\mathrm{n}}$ is the net radiation at the crop surface (MJ m ${ }^{-2}$ day $\left.{ }^{1}\right), \mathrm{G}$ the soil heat flux density $\left(\mathrm{MJ} \mathrm{m}^{-2} \mathrm{day}^{-1}\right)$, T the air temperature at $2 \mathrm{~m}$ height $\left({ }^{0} \mathrm{C}\right), \mathrm{u}_{2}$ the wind speed at $2 \mathrm{~m}$ height $\left(\mathrm{m} \mathrm{s}^{-1}\right), \mathrm{e}_{\mathrm{s}}$ the vapour pressure of the air at saturation $(\mathrm{kPa}), \mathrm{e}_{\mathrm{a}}$ the actual vapour pressure $(\mathrm{kPa}), \Delta$ the slope of the vapour pressure curve $\left(\mathrm{kPa}^{0} \mathrm{C}^{-1}\right)$ and $\gamma$ is the psychrometric constant $\left(\mathrm{kPa}^{0} \mathrm{C}^{-1}\right)$. 
According to Allen et al. (1998) the Rs value is calculated based on the Angstrom formula associated with extracellular radiation $(\mathrm{Ra})$ or angot radiation and the relative duration of sunlight $(\mathrm{n} / \mathrm{N})$. The value of Rs depends on the condition of the atmosphere and the declination of the sun (latitude and moon). Angstrom values of as and bs vary and are recommended $a_{s}=0.25$ and $b_{s}=0.50$ (Allen et al., 1998).

\section{Calculate the value CH - ETp}

where $\mathrm{CH}$ is rainfall $(\mathrm{mm}), \mathrm{ETp}$ is evapotranspiration.

1. Calculate the Accumulation of Potential Water Loss (APWL) which is the sum of the accumulative values $\mathrm{CH}-$ ETp which is negative.

2. Calculate the value KAT based on the equation ;

$\mathrm{KAT}=\mathrm{KL} \exp ^{(\mathrm{APWL} / \mathrm{KL})}$

where KAT is soil water content, KL is field capacity

3. Calculate the value $\triangle \mathrm{KAT}$ with the equation ;

$\mathrm{dKAT}=\mathrm{KAT}_{\mathrm{i}}-\mathrm{KAT}_{\mathrm{i}-1}$

where dKAT is difference one period KAT with the previous period. A positive KAT score indicates the addition of groundwater content. The negative KAT value indicates a reduction in groundwater content.

4. Calculating the actual evapotranspiration value (ETa) based on the equation ;

if $\mathrm{CH}>\mathrm{ETp}$ so $\mathrm{ETa}=\mathrm{ETp}$.

if $\mathrm{CH}<\mathrm{ETp}$ so $\mathrm{ETa}=\mathrm{CH}+\Delta \mathrm{KAT}$.

Where dKAT value is an absolute value, it means the negative sign is ignored in the calculation. At $\mathrm{CH}<\mathrm{ETp}$ ETa will be lower than ETp

5. Deficit (D)

Deficit means reduced water for potential evapotranspiration, so the water deficit is the difference between the potential evapotranspiration value and the actual evapotranspiration $(\mathrm{D}=\mathrm{ETP}-\mathrm{ETA})$

6. Surplus (S)

Once the groundwater storage reaches the field capacity, excess rainfall is calculated as a water surplus. (CH ETP - dKAT).

\section{Stages of Vulnerability Calculation of Production}

This stage includes water adequacy index analysis and analysis of the potential decrease of rice production is done by approaching the water balance model of the plant. The estimation of crop production decline is in line with the extent of water shortage resulting in the non-fulfilment of water demand for potential evapotranspiration. The magnitude of the coefficient of plant production and the reduction of crop production from its maximum potential are as follows :

$\mathrm{y}=\frac{E T a}{E T p} \times 100 \%$

$\mathrm{ky}=\frac{E T p-E T a}{E T p} \times 100 \%=\left(1-\frac{E T a}{E T p}\right) \times 100 \%$

where $\mathrm{y}$ is the coefficient of plant production, ky is the coefficient of crop production decline, ETa is the actual evapotranspiration, ETp is a potential evapotranspiration of plants (Doorenbos and Kassam, 1979). Classification of the coefficient of decreasing corn production (Pramudia, 2008) that is in Table 1 below :

\section{Results And Discussion:- Land Water Balance}

Based on the analysis of the water balance in the district of Gorontalo (Bumela) using climatic data for 20 years (1997 to 2016) and land data in the form of field capacity (KL) and permanent wilting point (TLP). This analysis is needed to calculate the value of surplus and deficit every month. The difference in rainfall $(\mathrm{CH})$ and suppose potential evapotranspiration value (ETP) of FAO Penman-Monteith method will affect the groundwater reserves. Spano et al. (2009) suggest that the biggest problem in influencing the estimation of an ecosystem's evapotranspiration is the spatial variation of a microclimate of an ecosystem and the level of water stress by a plant population.

Based on the recapitulation of the results of the water balance analysis in Table 2 above in the district of Gorontalo (Bumela) where the first deficit month period occurred in July, August, September, October. In November the percentage of events was the same between deficit and surplus but categorized as a surplus because the average 
amount of rainfall is high compared to the incidence period between surplus and deficit. The second month deficit period occurs in February and March. Igbadun et al. (2007) stated that the productivity of maize has a relationship with the availability of water which affects a number of subjects such as cultivated corn varieties, groundwater crops (deficit or surplus) and applied irrigation technology.

The first surplus period occurred in November, December and January while the second surplus period occurred in April, May and June. Based on these results indicate that the district of Gorontalo (Bumela) and other areas in Gorontalo province follow the local rainfall pattern where this pattern is unimodal (one rain peak or rainy season ie in April, May and June) but contrary to the monsoon rain pattern where in April, May and June entered the transition to the dry season. The pattern of local rainfall is much influenced by the topography of the local area.

Based on the recapitulation of the results of the water balance analysis in Table 3 above in Boalemo (Dulupi) district where the monthly pattern of deficit and the month of surplus is the same as Gorontalo district (Bumela) but for Boalemo (Dulupi) district has a longer period of first deficit (5 months) ie July, August, September, October and November. Based on these results, Boalemo district has a longer deficit period, which is 7 months deficit and 5 months surplus compared to other regions. Garcia et al. (2009) suggested that the main focus due to climate variability, especially during the transition of soil water content with different conditions, soil temperature erratic triggers the size of evaporation and transpiration potentially disrupt the productivity of corn crops. Climate risks of drought and floods trigger the level of water availability in the root zone. Hassanli et al. (2009) adoption of appropriate irrigation schedules especially in the sensitive and critical corn-development phases required for efficient use of water.

Based on the recapitulation of the results of the water balance analysis in Table 4 above in the district of Bone Bolango (Suwawa) where the first 3 month deficit period is 3 months ie in July, August, September. The second month period is the second deficit of 2 months ie in February and March. The first 4-month surplus period occurred in October, November, December and January while the second 3 month surplus period occurred in April, May and June. Based on these results, Bone Bolango (Suwawa) district has a longer surplus period, ie, for 7 months surplus and 5 months deficit compared to other regions.

Based on the recapitulation of the results of the water balance analysis in Table 5 above in the district of Pohuwato (Marisa) where the period of the first 4 month deficit month that occurs in July, August, September and October. The second month period is the second deficit of 2 months ie in February and March. The first 3 months surplus period is November, December and January while the second 3 month surplus period is April, May and June. Based on these results, the district of Pohuwato (Marisa) as a whole has 6 months of deficit and 6 months of surplus.

\section{The Vulnerability of Maize Production}

Based on Figure 1 above, maize production is susceptible to water shortage in 1997, 1998, 2002, 2006, 2009, 2015 and 2016 were in that year it was generally the case of Elnino (long dry season). The susceptibility of maize production due to lack of water occurred over a long period of time in 1997 and 1998 ie for 10 months starting July, August, September, October, November December 1997 to January, February, March, April 1998 with the value of coefficient of production decrease ky) close to the value of 1 of 0.83 with the category very vulnerable. Geerts and Raes (2009) state that there is a concept of irrigation deficit to optimize maize production during a period of deficit where the concept describes to be understood when there is a deficit then how to optimize irrigation in sensitive phases such as early growth, flowering, initial filling of grain.

Resistant maize production due to excess water occurred in late 1998, 1999, 2000, 2008, 2013 wherein those years generally experienced La Nina (long rainy season). In those years the value of the coefficient of production decrease (ky) close to 0 in a very resistant category. Ren et al. (2008) stated that the number and distribution of seasonal rainfall and have a major impact on corn production in the early stages of development occurs, the addition of biomass (vegetative and generative) significantly. On the other hand, the supply of excess water can disrupt corn production due to nutrient leaching, flood disasters caused by excessive runoff and landslides.

\section{Conclusions:-}

Generally, Gorontalo Province has the first deficit month period in July, August, September, October where during this period there is potential for maize production vulnerability (ky approaching 
1) due to the shortage of water supply. The period of the first surplus month is November, December, January where during this period there is potential resistance to corn production due to water availability (ky approaching 0 ). The second deficit period is February, March where during this period potentially less vulnerable due to short deficit period compared to period of first deficit month. The second surplus period is April, May, June where this period is potentially less resistant because the amount, distribution and duration of rainfall is relatively decreased compared to the first surplus period.

The susceptibility and resistance of maize production is influenced by the amount of supply and duration (duration of period) of regional rainfall and the application of adaptation technology to drought and flood disasters.

Table 1:-Classification of coefficient decrease of corn production

\begin{tabular}{|l|l|l|}
\hline $\begin{array}{l}\text { Coefficient decrease of corn } \\
\text { production (ky) }\end{array}$ & Category & Score \\
\hline $0,5-1,0$ & Very vulnerable & 1 \\
$0,3-0,5$ & vulnerable & 2 \\
$0,15-0,3$ & Medium & 3 \\
$0,05-0,15$ & Resistant & 4 \\
$0,00-0,05$ & Very Resistant & 5 \\
\hline
\end{tabular}

Table 2:-Water Balance of Maize of Gorontalo District (Bumela) for 20 Years (1997 - 2016)

\begin{tabular}{|c|c|c|c|c|c|c|c|c|c|c|c|c|}
\hline \multirow[t]{2}{*}{ Years } & \multicolumn{12}{|c|}{ Month } \\
\hline & Jan & Feb & Mar & Apr & Mei & Jun & Jul & Aug & Sep & Okt & Nov & Des \\
\hline 1997 & $S$ & $\mathrm{~N}$ & $\mathrm{~S}$ & $\mathrm{D}$ & $\mathrm{N}$ & $\mathrm{D}$ & D & $\mathrm{D}$ & $\mathrm{D}$ & D & $\mathrm{N}$ & D \\
\hline 1998 & $\mathrm{~N}$ & $\mathrm{D}$ & $\mathrm{D}$ & $\mathrm{D}$ & $S$ & $\mathrm{~N}$ & $S$ & $\mathrm{D}$ & $\mathrm{D}$ & $\mathrm{N}$ & $\mathrm{S}$ & $S$ \\
\hline 1999 & $S$ & $D$ & $S$ & $S$ & $S$ & $\mathrm{~N}$ & $\mathrm{~N}$ & $\mathrm{D}$ & $D$ & $\mathrm{~N}$ & $\mathrm{~N}$ & $\mathrm{D}$ \\
\hline 2000 & $S$ & $S$ & D & D & D & $S$ & D & D & D & $S$ & $S$ & D \\
\hline 2001 & $S$ & $S$ & $\mathrm{~N}$ & $S$ & $S$ & $S$ & D & D & D & D & $S$ & $S$ \\
\hline 2002 & $S$ & $\mathrm{D}$ & $\mathrm{D}$ & $\mathrm{N}$ & $\mathrm{N}$ & $\mathrm{D}$ & $\mathrm{D}$ & $\mathrm{D}$ & $\mathrm{D}$ & $\mathrm{D}$ & $D$ & $\mathrm{D}$ \\
\hline 2003 & D & D & $S$ & $S$ & $S$ & D & D & D & D & D & D & $S$ \\
\hline 2004 & $\mathrm{~N}$ & D & D & $S$ & $\mathrm{~N}$ & D & D & D & D & D & $D$ & D \\
\hline 2005 & $\mathrm{D}$ & D & $\mathrm{D}$ & D & $S$ & $\mathrm{D}$ & $S$ & $\mathrm{D}$ & $\mathrm{D}$ & $S$ & $D$ & $\mathrm{~N}$ \\
\hline 2006 & $\mathrm{~N}$ & $S$ & D & $S$ & $\mathrm{D}$ & $S$ & D & D & $\mathrm{D}$ & D & $S$ & $\mathrm{~N}$ \\
\hline 2007 & $S$ & D & D & $\mathrm{N}$ & $S$ & $S$ & D & D & D & D & $\mathrm{D}$ & $S$ \\
\hline 2008 & $S$ & D & $S$ & $S$ & $S$ & $S$ & $S$ & $S$ & D & $S$ & $S$ & $S$ \\
\hline 2009 & $S$ & $S$ & $S$ & $S$ & $S$ & $\mathrm{~N}$ & D & D & D & D & $\mathrm{N}$ & D \\
\hline 2010 & D & D & D & $S$ & $\mathrm{~S}$ & $S$ & $S$ & $\mathrm{~S}$ & $S$ & $S$ & D & $S$ \\
\hline 2011 & D & $S$ & $S$ & $\mathrm{~N}$ & $\mathrm{~N}$ & $S$ & D & D & D & $S$ & D & $S$ \\
\hline 2012 & D & D & D & $S$ & $S$ & $S$ & $S$ & D & D & D & $S$ & D \\
\hline 2013 & $S$ & $S$ & $\mathrm{D}$ & $S$ & $S$ & $\mathrm{~N}$ & $S$ & $S$ & $\mathrm{D}$ & $S$ & $\mathrm{D}$ & $S$ \\
\hline 2014 & $S$ & D & D & $\mathrm{N}$ & $S$ & $\mathrm{~N}$ & D & D & $D$ & D & $S$ & $S$ \\
\hline 2015 & D & D & D & D & $S$ & $S$ & D & D & D & D & $S$ & D \\
\hline 2016 & D & D & D & D & $S$ & $S$ & $S$ & D & D & $S$ & $\mathrm{~N}$ & $S$ \\
\hline Surplus & $50 \%$ & $30 \%$ & $30 \%$ & $50 \%$ & $70 \%$ & $50 \%$ & $35 \%$ & $15 \%$ & $5 \%$ & $35 \%$ & $40 \%$ & $50 \%$ \\
\hline Normal & $15 \%$ & $5 \%$ & $5 \%$ & $20 \%$ & $20 \%$ & $25 \%$ & $5 \%$ & $0 \%$ & $0 \%$ & $10 \%$ & $20 \%$ & $10 \%$ \\
\hline Deficit & $35 \%$ & $65 \%$ & $65 \%$ & $30 \%$ & $10 \%$ & $25 \%$ & $60 \%$ & $85 \%$ & $95 \%$ & $55 \%$ & $40 \%$ & $40 \%$ \\
\hline Water Balance & $\mathrm{S}$ & $\mathrm{D}$ & $\mathrm{D}$ & $\mathrm{S}$ & $S$ & $S$ & D & D & D & D & $S / D$ & $S$ \\
\hline
\end{tabular}

Table 3:-Water Balance of Maize of Boalemo District (Dulupi) for 20 Years (1997 - 2016) 


\begin{tabular}{|c|c|c|c|c|c|c|c|c|c|c|c|c|}
\hline & Jan & Feb & Mar & Apr & Mei & Jun & Jul & Aug & Sep & Okt & Nov & Des \\
\hline 1997 & $S$ & $\mathrm{~N}$ & $\mathrm{~S}$ & $S$ & $\mathrm{~S}$ & D & $\mathrm{D}$ & $\mathrm{D}$ & D & D & $\mathrm{D}$ & $\mathrm{N}$ \\
\hline 1998 & $S$ & D & D & D & $S$ & $\mathrm{~N}$ & $S$ & $\mathrm{~N}$ & $S$ & $S$ & $S$ & $S$ \\
\hline 1999 & $\mathrm{~S}$ & $D$ & $S$ & $S$ & $\mathrm{~S}$ & $S$ & $\mathrm{~S}$ & $\mathrm{~N}$ & $\mathrm{~N}$ & $S$ & $\mathrm{~N}$ & $S$ \\
\hline 2000 & $S$ & $S$ & $D$ & $S$ & $S$ & $S$ & $D$ & $\mathrm{~N}$ & $\mathrm{~N}$ & $S$ & $S$ & $S$ \\
\hline 2001 & $S$ & $S$ & $S$ & $S$ & $S$ & $S$ & $D$ & D & $\mathrm{N}$ & $D$ & $S$ & $S$ \\
\hline 2002 & $S$ & $D$ & $\mathrm{~N}$ & $S$ & $S$ & $\mathrm{~N}$ & $D$ & $D$ & $D$ & $D$ & $\mathrm{D}$ & $S$ \\
\hline 2003 & $S$ & $D$ & $S$ & $S$ & $S$ & $D$ & $D$ & $D$ & $D$ & $D$ & $\mathrm{D}$ & $S$ \\
\hline 2004 & $S$ & D & D & $S$ & $S$ & D & D & D & D & D & D & $\mathrm{N}$ \\
\hline 2005 & D & D & D & $S$ & $S$ & D & $S$ & D & D & $S$ & D & $S$ \\
\hline 2006 & $S$ & $S$ & $D$ & $S$ & $S$ & $S$ & $D$ & $D$ & $\mathrm{~N}$ & $D$ & $S$ & $S$ \\
\hline 2007 & $S$ & $\mathrm{D}$ & $\mathrm{D}$ & $\mathrm{N}$ & $S$ & $S$ & $D$ & $\mathrm{D}$ & $S$ & $\mathrm{D}$ & D & $S$ \\
\hline 2008 & $S$ & $\mathrm{D}$ & $S$ & $S$ & $S$ & $S$ & $S$ & $S$ & $S$ & $S$ & $S$ & $S$ \\
\hline 2009 & $S$ & $S$ & $S$ & $S$ & $S$ & $S$ & D & D & D & $\mathrm{D}$ & $\mathrm{N}$ & D \\
\hline 2010 & $S$ & D & D & $S$ & $S$ & $S$ & $S$ & $S$ & $S$ & $S$ & D & $S$ \\
\hline 2011 & $S$ & $S$ & $S$ & $S$ & $S$ & $S$ & $D$ & D & $\mathrm{N}$ & $S$ & D & $S$ \\
\hline 2012 & $S$ & $\mathrm{~N}$ & D & $S$ & $S$ & $S$ & $S$ & $S$ & $\mathrm{~N}$ & $S$ & $S$ & D \\
\hline 2013 & $S$ & $S$ & $D$ & $S$ & $S$ & $\mathrm{~N}$ & $S$ & $S$ & $\mathrm{~N}$ & $D$ & $\mathrm{D}$ & $S$ \\
\hline 2014 & $S$ & D & D & $S$ & $S$ & $\mathrm{~N}$ & $D$ & D & $D$ & D & $S$ & $S$ \\
\hline 2015 & $S$ & $D$ & $D$ & $D$ & $S$ & $S$ & $D$ & $D$ & $D$ & $D$ & $\mathrm{~N}$ & D \\
\hline 2016 & $S$ & $D$ & $D$ & D & $S$ & $S$ & $S$ & $\mathrm{D}$ & $D$ & $S$ & $\mathrm{~N}$ & $S$ \\
\hline Surplus & $95 \%$ & $30 \%$ & $35 \%$ & $80 \%$ & $100 \%$ & $60 \%$ & $40 \%$ & $20 \%$ & $20 \%$ & $45 \%$ & $35 \%$ & $75 \%$ \\
\hline Normal & $0 \%$ & $10 \%$ & $5 \%$ & $5 \%$ & $0 \%$ & $20 \%$ & $0 \%$ & $15 \%$ & $35 \%$ & $0 \%$ & $20 \%$ & $10 \%$ \\
\hline Deficit & $5 \%$ & $60 \%$ & $60 \%$ & $15 \%$ & $0 \%$ & $20 \%$ & $60 \%$ & $65 \%$ & $45 \%$ & $55 \%$ & $45 \%$ & $15 \%$ \\
\hline Water Balance & $\mathrm{S}$ & $\mathrm{D}$ & $\mathrm{D}$ & S & $S$ & $\mathrm{~S}$ & $\mathrm{D}$ & $\mathrm{D}$ & $\mathrm{D}$ & $\mathrm{D}$ & D & $S$ \\
\hline
\end{tabular}

Table 4:-Water Balance of Maize of Bone Bolango (Suwawa) for 20 Years (1997 - 2016)

\begin{tabular}{|c|c|c|c|c|c|c|c|c|c|c|c|c|}
\hline \multirow[t]{2}{*}{ Years } & \multicolumn{12}{|c|}{ Month } \\
\hline & Jan & Feb & Mar & Apr & Mei & Jun & Jul & Aug & Sep & Okt & Nov & Des \\
\hline 1997 & $S$ & $\mathrm{~N}$ & $S$ & $S$ & $S$ & $\mathrm{D}$ & $\mathrm{D}$ & $\mathrm{D}$ & $\mathrm{D}$ & $\mathrm{N}$ & $\mathrm{N}$ & $\mathrm{N}$ \\
\hline 1998 & $S$ & D & D & D & $S$ & $\mathrm{~N}$ & $S$ & $\mathrm{~N}$ & $S$ & $S$ & $S$ & $S$ \\
\hline 1999 & $S$ & $\mathrm{~N}$ & $S$ & $S$ & $S$ & $S$ & $S$ & $\mathrm{~N}$ & $\mathrm{~N}$ & $S$ & $\mathrm{~N}$ & $S$ \\
\hline 2000 & $S$ & $S$ & $\mathrm{~N}$ & $S$ & $S$ & $S$ & D & $\mathrm{N}$ & $\mathrm{N}$ & $S$ & $S$ & $S$ \\
\hline 2001 & $S$ & $S$ & $S$ & $S$ & $S$ & $S$ & $D$ & $D$ & $\mathrm{~N}$ & $\mathrm{~N}$ & $S$ & $S$ \\
\hline 2002 & $S$ & $\mathrm{~N}$ & $\mathrm{~N}$ & $S$ & $S$ & $\mathrm{~N}$ & D & D & D & D & D & $S$ \\
\hline 2003 & $S$ & $\mathrm{D}$ & $S$ & $S$ & $S$ & D & $D$ & $\mathrm{D}$ & $\mathrm{D}$ & $\mathrm{D}$ & D & $S$ \\
\hline 2004 & $S$ & $D$ & $D$ & $S$ & $S$ & $\mathrm{~N}$ & $\mathrm{D}$ & $\mathrm{D}$ & $\mathrm{D}$ & $\mathrm{D}$ & $\mathrm{N}$ & $\mathrm{N}$ \\
\hline 2005 & $S$ & $\mathrm{~N}$ & $D$ & $S$ & $S$ & $\mathrm{~N}$ & $S$ & $D$ & $D$ & $S$ & $S$ & $S$ \\
\hline 2006 & $S$ & $S$ & D & $S$ & $S$ & $S$ & D & D & $\mathrm{N}$ & D & $S$ & $S$ \\
\hline 2007 & $S$ & $\mathrm{D}$ & $\mathrm{N}$ & $\mathrm{N}$ & $S$ & $S$ & D & D & $S$ & $\mathrm{D}$ & D & $S$ \\
\hline 2008 & $S$ & $\mathrm{D}$ & $S$ & $S$ & $S$ & $S$ & $S$ & $S$ & $S$ & $S$ & $S$ & $S$ \\
\hline 2009 & $S$ & $S$ & $S$ & $S$ & $S$ & $S$ & $\mathrm{D}$ & $\mathrm{D}$ & $\mathrm{D}$ & $\mathrm{N}$ & $\mathrm{N}$ & $D$ \\
\hline 2010 & $S$ & D & D & $S$ & $S$ & $S$ & $S$ & $S$ & $S$ & $S$ & D & $S$ \\
\hline 2011 & $S$ & $S$ & $S$ & $S$ & $S$ & $S$ & D & D & $\mathrm{N}$ & $S$ & D & $S$ \\
\hline 2012 & $S$ & $\mathrm{~N}$ & D & $S$ & $S$ & $S$ & $S$ & $S$ & $\mathrm{~N}$ & $S$ & $S$ & D \\
\hline 2013 & $S$ & $S$ & D & $S$ & $S$ & $\mathrm{~N}$ & $S$ & $S$ & $\mathrm{~N}$ & $S$ & D & $S$ \\
\hline
\end{tabular}




\begin{tabular}{|l|l|l|l|l|l|l|l|l|l|l|l|l|}
\hline 2014 & $\mathrm{~S}$ & $\mathrm{D}$ & $\mathrm{D}$ & $\mathrm{S}$ & $\mathrm{S}$ & $\mathrm{N}$ & $\mathrm{D}$ & $\mathrm{D}$ & $\mathrm{D}$ & $\mathrm{S}$ & $\mathrm{S}$ & $\mathrm{S}$ \\
\hline 2015 & $\mathrm{~S}$ & $\mathrm{D}$ & $\mathrm{D}$ & $\mathrm{D}$ & $\mathrm{S}$ & $\mathrm{S}$ & $\mathrm{D}$ & $\mathrm{D}$ & $\mathrm{D}$ & $\mathrm{D}$ & $\mathrm{N}$ & $\mathrm{D}$ \\
\hline 2016 & $\mathrm{~S}$ & $\mathrm{D}$ & $\mathrm{D}$ & $\mathrm{D}$ & $\mathrm{S}$ & $\mathrm{S}$ & $\mathrm{S}$ & $\mathrm{D}$ & $\mathrm{D}$ & $\mathrm{S}$ & $\mathrm{N}$ & $\mathrm{S}$ \\
\hline Surplus & $100 \%$ & $30 \%$ & $35 \%$ & $80 \%$ & $100 \%$ & $60 \%$ & $40 \%$ & $20 \%$ & $20 \%$ & $55 \%$ & $40 \%$ & $50 \%$ \\
\hline Normal & $0 \%$ & $25 \%$ & $15 \%$ & $5 \%$ & $0 \%$ & $30 \%$ & $0 \%$ & $15 \%$ & $35 \%$ & $15 \%$ & $30 \%$ & $10 \%$ \\
\hline Deficit & $0 \%$ & $45 \%$ & $50 \%$ & $15 \%$ & $0 \%$ & $10 \%$ & $60 \%$ & $65 \%$ & $45 \%$ & $30 \%$ & $30 \%$ & $40 \%$ \\
\hline Water balance & $\mathrm{S}$ & $\mathrm{D}$ & $\mathrm{D}$ & $\mathrm{S}$ & $\mathrm{S}$ & $\mathrm{S}$ & $\mathrm{D}$ & $\mathrm{D}$ & $\mathrm{D}$ & $\mathrm{S}$ & $\mathrm{S}$ & $\mathrm{S}$ \\
\hline
\end{tabular}

Table 5:-Water Balance of Maize of Pohuwato District (Marisa) for 20 Years (1997 - 2016)

\begin{tabular}{|c|c|c|c|c|c|c|c|c|c|c|c|c|}
\hline \multirow[t]{2}{*}{ Years } & \multicolumn{12}{|c|}{ Month } \\
\hline & Jan & Feb & Mar & Apr & Mei & Jun & Jul & Aug & Sep & Okt & Nov & Des \\
\hline 1997 & $S$ & $\mathrm{~N}$ & $S$ & $S$ & $S$ & $\mathrm{D}$ & $\mathrm{D}$ & D & $\mathrm{D}$ & $\mathrm{N}$ & $\mathrm{N}$ & $\mathrm{N}$ \\
\hline 1998 & $\mathrm{~S}$ & $\mathrm{D}$ & $\mathrm{D}$ & $\mathrm{D}$ & $\mathrm{D}$ & $\mathrm{N}$ & $S$ & $\mathrm{~N}$ & $\mathrm{~S}$ & $S$ & $S$ & $S$ \\
\hline 1999 & $\mathrm{~N}$ & $\mathrm{~N}$ & $S$ & $S$ & $S$ & $S$ & $S$ & $\mathrm{~N}$ & $\mathrm{~N}$ & $S$ & $\mathrm{~N}$ & $S$ \\
\hline 2000 & $S$ & $S$ & $\mathrm{~N}$ & $\mathrm{~N}$ & $S$ & $S$ & D & $\mathrm{N}$ & $\mathrm{N}$ & D & $S$ & $S$ \\
\hline 2001 & $S$ & $\mathrm{~N}$ & $S$ & $S$ & $\mathrm{~N}$ & $S$ & D & D & $\mathrm{N}$ & D & $S$ & $S$ \\
\hline 2002 & $S$ & $\mathrm{~N}$ & $\mathrm{~N}$ & $S$ & $\mathrm{~S}$ & $\mathrm{~N}$ & D & D & $\mathrm{D}$ & D & D & $S$ \\
\hline 2003 & $S$ & D & D & $S$ & $S$ & D & D & D & D & D & D & $S$ \\
\hline 2004 & $S$ & D & D & $S$ & $S$ & $\mathrm{~N}$ & D & D & $\mathrm{D}$ & D & $\mathrm{N}$ & $\mathrm{N}$ \\
\hline 2005 & $S$ & $\mathrm{~N}$ & D & $S$ & $S$ & $S$ & $S$ & $D$ & $\mathrm{D}$ & $S$ & $S$ & $S$ \\
\hline 2006 & $\mathrm{~N}$ & $S$ & $D$ & $\mathrm{~N}$ & $S$ & $S$ & $D$ & $\mathrm{~N}$ & $\mathrm{~N}$ & $D$ & $S$ & $S$ \\
\hline 2007 & $S$ & $D$ & $\mathrm{~N}$ & $\mathrm{~N}$ & $S$ & $S$ & $D$ & $D$ & $S$ & D & D & $S$ \\
\hline 2008 & $S$ & $D$ & $S$ & $S$ & $S$ & $S$ & $S$ & $S$ & $S$ & $\mathrm{~N}$ & $S$ & $S$ \\
\hline 2009 & $S$ & $S$ & $S$ & $S$ & $S$ & $S$ & $D$ & $D$ & D & $\mathrm{N}$ & $\mathrm{N}$ & $\mathrm{D}$ \\
\hline 2010 & $S$ & $S$ & D & $S$ & $S$ & $S$ & $S$ & $S$ & $S$ & $\mathrm{~N}$ & D & $S$ \\
\hline 2011 & $S$ & $S$ & $S$ & $S$ & $S$ & $S$ & D & D & $\mathrm{N}$ & $S$ & D & $S$ \\
\hline 2012 & $S$ & $S$ & D & $S$ & $S$ & $S$ & $S$ & $S$ & $\mathrm{~N}$ & $S$ & $S$ & $\mathrm{~N}$ \\
\hline 2013 & $S$ & $S$ & D & $S$ & $S$ & $\mathrm{~N}$ & D & D & $\mathrm{N}$ & $S$ & D & $\mathrm{N}$ \\
\hline 2014 & $\mathrm{~N}$ & $\mathrm{D}$ & $\mathrm{D}$ & $S$ & $S$ & $\mathrm{~N}$ & $\mathrm{D}$ & $\mathrm{D}$ & $\mathrm{D}$ & $S$ & $S$ & $S$ \\
\hline 2015 & $S$ & $\mathrm{D}$ & D & $\mathrm{D}$ & $S$ & $S$ & $\mathrm{D}$ & D & D & $\mathrm{D}$ & $\mathrm{N}$ & D \\
\hline 2016 & $S$ & $\mathrm{D}$ & $\mathrm{D}$ & $\mathrm{D}$ & $S$ & $S$ & $S$ & D & $\mathrm{D}$ & D & $\mathrm{N}$ & $S$ \\
\hline Surplus & $85 \%$ & $35 \%$ & $30 \%$ & $70 \%$ & $90 \%$ & $65 \%$ & $35 \%$ & $15 \%$ & $20 \%$ & $35 \%$ & $40 \%$ & $70 \%$ \\
\hline Normal & $15 \%$ & $25 \%$ & $15 \%$ & $15 \%$ & $5 \%$ & $25 \%$ & $0 \%$ & $15 \%$ & $35 \%$ & $20 \%$ & $30 \%$ & $20 \%$ \\
\hline Deficit & $0 \%$ & $40 \%$ & $55 \%$ & $15 \%$ & $5 \%$ & $10 \%$ & $65 \%$ & $70 \%$ & $45 \%$ & $45 \%$ & $30 \%$ & $10 \%$ \\
\hline Water Balance & $S$ & $\mathrm{D}$ & $\mathrm{D}$ & $\mathrm{S}$ & $S$ & $S$ & $\mathrm{D}$ & $\mathrm{D}$ & $\mathrm{D}$ & $\mathrm{D}$ & $\mathrm{S}$ & $S$ \\
\hline
\end{tabular}



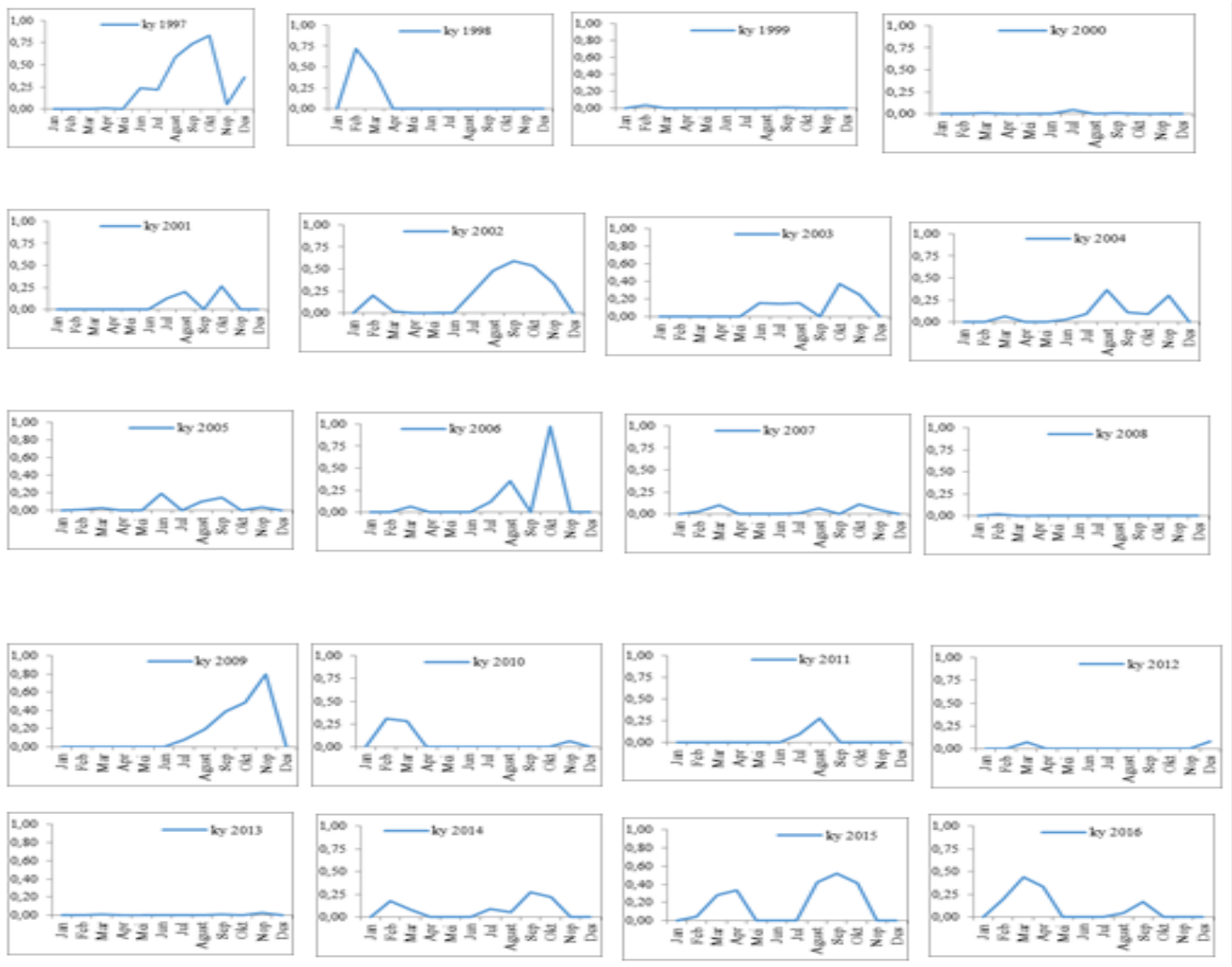

\section{References:-}

1. Allen G. R., L. S. Pereira., D. Raes., M. Smith. 1998. Crop Evapotranspirations (Guidelines for Computing Crop Water Requirements). FAO Irrigation and Drainage Paper 56.

2. Cai Jiabing., Yu Liu, Tingwu Lei, Luis Santos Pereira. 2007. Estimating reference evapotranspiration with the FAO Penman-Monteith equation using daily weather forecast messages. Agricultural and Forest Meteorology J.145. 22 https://www.researchgate.net/publication/222165945_Estimating_reference_evapotranspiration_with_the_FAO _Penman-Monteith_equation_using_daily_weather_forecast_messages

3. Doorenbos, J., Kassam, A.H., 1979. Yield response to water. FAO Irrigation and Drainage Paper, No. 33, FAO, Rome, Italy.

4. Farre, I., J. M. Faci. 2009. Deficit Irrigation In Maize for Reducing Agricultural Water Use In a Mediterranean Environment. Agricultural Water Management J. 96.4383 - 394. https://www.researchgate.net/publication/23990936_Deficit_irrigation_in_maize_for_reducing_agricultural_wa ter_use_in_a_Mediterranean_environment

5. Garcia, Axel. Y. Garcia., Larry C. Guerra, Gerrit Hoogenboom. 2009. Water use and water use efficiency of sweet corn under different weather conditions and soil moisture regimes. Agricultural Water Management J. 96. 1369

1376. https://www.researchgate.net/publication/222408853_Water_use_and_water_use_efficiency_of_sweet_corn_un der_different_weather_conditions_and_soil_moisture_regimes

6. Geerts, Sam., Dirk Raes. 2009. Deficit Irrigation as an on Farm Strategy to Maximize Crop Water Productivity in Dry Areas. Agricultural Water Management J. 96.1275 - 1284. https://www.researchgate.net/publication/222526607_Deficit_irrigation_as_an_onfarm_strategy_to_maximise_crop_water_production_in_dry_areas

7. Hakim, Luthful M. Model Pendugaan Banjir dan Kekeringan (Studi Kasus Di DAS Separi, Kutai Kertanegara Kalimantan Timur). Disertasi. Institut Pertanian Bogor. http://repository.ipb.ac.id/handle/123456789/40991 
8. Hassanli, Morad. Ali., Mohammed Ali. Ebrahimizadeh., Simon Beecham. 2009. The Effects of Irrigation Methods with Effluent and Irrigation Scheduling on Water Use Efficiency and Corn Yields In an Arid Region. $\begin{array}{lllllll}\text { Agricultural } & \text { Water } & \text { Management } & \text { J. } & 96 . & 93 & -\end{array}$ https://www.researchgate.net/publication/23629651_The_effects_of_irrigation_methods_with_effluent_and_irri gation_scheduling_on_water_use_efficiency_and_corn_yields_in_an_and_region

9. Igbadun, E. Henry., Andrew K.P.R. Tarimo., Baanda A. Salim., Henry F. Mahoo. 2007. Evaluation of Selected Crop Water Production Function for an Irrigated Maize Crop. Agricultural Water Management J. 94.1 - 10. http://www.academia.edu/2119045/Evaluation_of_selected_crop_water_production_functions_for_an_irrigated _maize_crop

10. Katerji Nader., Gianfranco Rana. 2006. Modelling evapotranspiration of six irrigated crops under Mediterranean climate conditions. Agricultural and Forest Meteorology J. $138.142 \quad-\quad 155$. https://www.researchgate.net/publication/222114802_Modelling_evapotranspiration_of_six_irrigated_crops_un der_Mediterranean_climate_conditions

11. Ko Jonghan., Giovanni Piccinni. 2009. Corn Yield Responses under Crop Evapotranspiration Based Irrigation

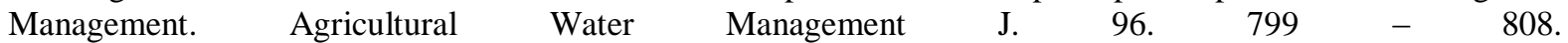
http://www.sciencedirect.com/science/article/pii/S0378377408002849

12. Payero, J. O., D. D. Tarkalson., S. Irmak., D. Davison., J. L. Peterson. 2009. Effect of Timing of a DeficitIrrigation Allocation on Corn Evapotranspiration, Yield, Water Use Efficiency and Dry Mass. Agricultural $\begin{array}{lllllll}\text { Water } & \text { Management } & \text { J. } & 96 . & 1387 & - & 1397 .\end{array}$ https://www.researchgate.net/publication/46488843_Effect_of_Timing_of_a_DeficitIrrigation_Allocation_on_Corn_Evapotranspiration_Yield_Water_Use_Efficiency_and_Dry_Mass

13. Pramudia A. 2008. Pewilayahan Hujan dan Model Prediksi Curah Hujan untuk Mendukung Analisis Ketersediaan dan Kerentanan Pangan di Sentra produksi Padi. Disertasi. Institut Pertanian Bogor. Bogor. http://repository.ipb.ac.id/handle/123456789/41261

14. Ren, Xiaolong., Zhikuan Jia., Xiaoli Chen. 2008. Rainfall Concentration for Increasing Corn Production Under Semiarid Climate. Agricultural Water Management J. $\quad 95 . \quad 1293-1302$. https://agwaterconservation.colostate.edu/library/rainfall-concentration-for-increasing-corn-production-undersemiarid-climate/

15. Spano, D., D. L. Synder., C. Sirca., P. Duce. 2009. ECOWAT-A model for ecosystem evapotranspiration estimation. Agricultural and Forest Meteorology J. 149. 1584 - 1596.

16. Suyker E, Andrew., Shashi B Verma. 2009. Evapotranspiration of irrigated and rainfed maize-soybean cropping systems. Agricultural and Forest Meteorology J. $149.443 \quad-\quad 452$. https://www.researchgate.net/publication/222523228_Evapotranspiration_of_Irrigated_and_Rainfed_MaizeSoybean_Cropping_Systems

17. Tao, Fulu., Zhao Zhang. 2010. Adaptation of Maize Production to Climate Change in North China Plain : Quantify the Relative Contribution of Adaptation Options. Europ J. Agronomy. 33. 103 - 116. https://www.researchgate.net/publication/228419627_Adaptation_of_maize_production_to_climate_change_in _North_China_Plain_Quantify_the_relative_contributions_of_adaptation_options. 